\title{
Die gedig as 'n vreemdeling se graf
}

\section{Die gedig as ' $n$ vreemdeling se graf}

\section{I}

Wonder of dié dag my iets gaan leer van jou skielike afsterwe,

jy wat nog nie eens gedagte of gedigte was nie. Brand elke nag

die maan met jou lyf wanneer jy kaal onder grond vrugbaar

weer deel word van die aarde. Proe

elke wurm sag deur jou

lyf. Ag, om te ontsnap uit die woorde wanneer ek nie eens

weet wie of wat jy is nie, jy vir wie ek skryf, ses voet onder?

\section{II}

Geen mens het jou weer gesien nadat ek jou in die gedig begrawe het nie. Aan die kis van woorde hoor ek jou krap, proe aan wurms in jou mond, hulle wat hap na hap die vrekte vier. Vraatsugtig byt jy nog aan grond asof jy nooit genoeg daarvan sal kry nie. Eendag op 'n reëndag sal ek met geen vermoede van ontmoeting op jou graf trap en ril.

\section{III}

Wanneer al die slaap van "vir ewig" verbygaan, sal ek en jy - daar onder - die sjampanjebottels uit die kaste van die ewigheid haal en drink op dit wat ons nooit geken het nie. Ons sal mekaar vier en dink: As ons net vroeër in hierdie vreemde liggaamloosheid was, sou ons -aan- geloop het soos verliefdes hand-aan-hand.

\section{IV}

In jou geraamte-arm se kuil hou ek my skuil; die

benerigheid van vergaan is

aanvanklik hard, maar sagter

soos die jare kom en gaan. Die warm water filtreer

deur muwwe grond. Wat sal die mense sê as hulle ons

saam daar onder in die kis langs mekaar sien lê? "Is 'n kis nie 'n baie private ding nie?" Ag, om ewighede aan jou te ruik!
V

Die eerste keer binne 'n donker kelder onthou ek goed.

Daarna wou ek nooit weer na die kelder teruggaan nie.

Die eerste keer het ek kennis gemaak met die donker. Ek het nooit

weer teruggegaan nie. Ek droom meestal dat ek nie wil doodgaan nie.

Die kis klap toe en ek haal nog asem. Ek krap met pen teen die kis se klap. Jare later vind julle die gedig: Jul 't van my vergeet.
Die gedig as ' $n$ vreemdeling se graf $I$ Ek wonder of dié dag my iets gaan leer van jou skielike afsterve jy wat nog nie eens ge-
dagte of gedigte was nie. Jy brand elke nag die maan met jou lyf dagte of gedigte was nie. Jy brand elke nag die maan met jou h
wanneer jy kaal onder vrugbare grond weer de $\mathcal{A}$ word van die wanneer jy kaal onder vrugbare grond weer dę $\mathrm{A}$ word van die
aarde. Jy proe elke wurm sag deur jou lyf. Ag, hoe kan ek ontsnap uit die woorde wanneer ek nie

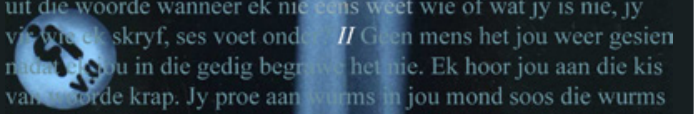 vap na hap die vrekte vier. $\mathrm{V}_{1} \quad$ ins inti: byt jy nog aan grond asof $\begin{array}{ll}\text { hap na hap die vrekte vier. Vi } & \text { igti. byt jy nog aan grond asof } \\ \text { jy nooit genoeg daarvan sal k } & \text { c. E. nda. op 'n reëndag sal ek }\end{array}$ met geen vermoede van ontnoeting of jou gaf trap en ril. III Wanneer al die slaap van "vir enwit" vygaan, sal ek en jy - daar onder - die sjampanjebottels uit die $\mathrm{ke}$ te van die ewigheid haal en drink op dit wat ons nooit geken he nie. Ons sal mekaar vier en dink: As ons net vroeër in hierdie ve-emde vorm van beyond body was, sou ons -aan-geloop het sou verliefdes hand-aan- hand. $I V$ Ek hou my skuil in jou ger an e-arm se kuil; die be- nerigheid van vergaan is aanvank ha , maar raak al sagter soos die jare kom en gaan. Die wari $\quad$ reer deur muwwe grond. Wat sal die mense sê as hulle of_ conar onder in die kis langs mekaar sien lê? "Is 'n kis nier Jalle ph vate ding nie?" Ag, om ewighede aan jou te ruik! $V$. eerste keer toe ek binne 'n donker kelder gestaan he aarna w.
VI
Ag, hoe goed om eindelik te ontmoet. Jy het ook asemgehaal soos duisende ander. Ook gestink en eindelik opgehou met stink. Jy het lank in die grond baljaar. Gespeel in 'n sandput - kastele gebou.
Nou klim jy agter my in soos wanneer ons saam sou bad. Onthou jy?
Maar jy kan nie onthou nie. Ek het jou nooit ontmoet nie. Ek het jou verbeel; ek het elkeen van julle verbeel en die woorde het reeds ontbind. na die kelder nie. Die eerste kcow het ek _unis gemaak met die donker. Ek het nooit ween tenn Ek droom meestal dat ek nie wil doodgaan nie. krap met pen teen die kis torap ue later vind /ulle die gedig Jul't van my vergeet. VI As,
het ook asemgehaal soos duiscinde eindelik opgehou met stink. Jy het la Gespeel in 'n sandput - kastele gebou. Nouklii' soos wanneer ons saam sou bad. Onthou jy? Ma onthou nie. Ek het jou nooit ontmoet nie. het elkeen van julle verbeel en die woorde het eds ontbind. 